\title{
Warm-based basal sediment entrainment and far-field Pleistocene origin evidenced in central Transantarctic blue ice through stable isotopes and internal structures
}

\author{
JOSEPH A. GRALY, ${ }^{1}$ KATHY J. LICHT, ${ }^{1}$ CHRISTINE M. KASSAB,${ }^{1}$ BROXTON W. BIRD, ${ }^{1}$ \\ MICHAEL R. KAPLAN ${ }^{2}$ \\ ${ }^{1}$ Department of Earth Sciences, Indiana University Purdue University Indianapolis, Indianapolis, IN, USA \\ ${ }^{2}$ Lamont-Doherty Earth Observatory, Palisades, NY, USA \\ Correspondence: Joseph A. Graly <jgraly@iupui.edu>
}

\begin{abstract}
Stable isotopes of water $\left(\delta^{18} \mathrm{O}\right.$ and $\left.\delta^{2} \mathrm{H}\right)$ were measured in the debris-laden ice underlying an Antarctic blue ice moraine, and in adjoining Law Glacier in the central Transantarctic Mountains. Air bubble content and morphology were assessed in shallow ice core samples. Stable isotope measurements plot either on the meteoric waterline or are enriched from it. The data cluster in two groups: the ice underlying the moraine has a $\delta^{2} \mathrm{H}: \delta^{18} \mathrm{O}$ slope of $5.35 \pm 0.92$; ice from adjoining portions of Law Glacier has a slope of $6.69 \pm 1.39$. This enrichment pattern suggests the moraine's underlying blue ice entrained sediment through refreezing processes acting in an open system. Glaciological conditions favorable to warm-based sediment entrainment occur $30-50 \mathrm{~km}$ upstream. Basal melting and refreezing are further evidenced by abundant vapor figures formed from internal melting of the ice crystals. Both the moraine ice and Law Glacier are sufficiently depleted of heavy isotopes that their ice cannot be sourced locally, but instead must be derived from far-field interior regions of the higher polar plateau. Modeled ice flow speeds suggest the ice must be at least 80 ka old, with Law Glacier's ice possibly dating to OIS 5 and moraine ice older still.
\end{abstract}

KEYWORDS: blue ice, ice core, subglacial processes, subglacial sediments

\section{INTRODUCTION}

Glaciers and ice sheets are important agents of sediment transport and geomorphic change, but the rate of sediment cycling depends considerably on glacial dynamics and the thermal properties of the ice body. Major differences in the effect of glaciers on landscapes exist between cold-based and warm-based ice, and between regions where surface meltwater is routed to the bed and regions that are too cold to allow for surface melt (Alley and others, 1997). Much of the sediment transport and erosion performed by glaciers occurs within a several-meter-thick basal ice layer. Within basal ice layers, sediment can either be dispersed throughout the ice (typically in low concentrations) or laminated in distinct layers; grain size distributions in basal sediments can range from clay to boulder-sized particles (Knight, 1997). The highest erosion rates are found in warm-based, tectonically active settings (Hallet and others, 1996). However, active erosion and deposition in cold-based glacier settings are sometimes evidenced by the geomorphology of the glaciers and the nature of sediment deposits (Atkins and others, 2002).

The physical mechanisms underlying the entrainment of debris in ice have long been considered by glaciologists (e. g. Weertman, 1961). The two primary mechanisms are regelation, whereby ice melts and refreezes around sediment grains under the pressure of the overlying ice (Philip, 1980; Hubbard and Sharp, 1993) and freeze-on through glaciohydraulic super cooling, whereby adverse gradients in bed slope cause the change in pressure melting point to exceed heat generated by motion (Lawson and others, 1998). Freeze-on processes transfer sediment from the bed to the overlying ice and in the process also draw porewater from till to form the clean or dirty ice layers of ice stream beds (Christoffersen and others, 2006). Both these mechanisms are typically conceived as occurring in warm-based ice, yet sediment entrainment is documented in settings known to contain only cold-based ice. For example, sediment entrainment in an ice bed with temperatures as cold as $-17^{\circ} \mathrm{C}$ was attributed to interfacial films of liquid water capable of performing regelation where bulk melting does not occur (Cuffey and others, 2000). Such interfacial films allow entrainment of sediment at temperatures as low as $-30^{\circ} \mathrm{C}$ under laboratory conditions (Dash and others, 2006). Shearing entrainment mechanisms are evident in sub-freezing beds where actively deforming ice rides up against stagnant or rigid ice and entrains sediment through interfacial processes (Chinn, 1991; Tison and others, 1993). In the absence of ice temperature measurements at the location of sediment entrainment, the distinction between warm-based and cold-based entrainment mechanisms is inferred from indirect evidence such as stable isotopes and ice texture.

In this study, we employ stable isotopes and shallow ice core texture analyses to better understand debris delivery to Antarctic blue ice moraines and the age of the ice from which the moraines derive. Blue ice moraines occur laterally along distributary outlet glaciers and ice streams that pass between mountains or by nunataks and are common in regions such as the Transantarctic Mountains. Sublimation in blue ice areas draws in the ice that underlies the ablating surface. Such upwardly fluxing ice often contain meteorites (Whillans and Cassidy, 1983) and archives of past glacial periods (Bintanja, 1999; Turney and others, 2013). The 
sediments that emerge at the termini of blue ice areas are presumed to come from the basal ice layers of the adjoining glacial outlet, and their accumulation forms the blue ice moraines (Bader and others, 2017). Blue ice moraines have been frequently studied as terrestrial repositories of Antarctica's subglacial sediment and unexposed rock types (Palmer and others, 2012), aiding in the reconstruction of past ice-sheet behavior (Fogwill and others, 2012; Sugden and others, 2014; Licht and Hemming, 2017). We have two principal objectives in analyzing the stable isotopes and ice core textures of blue ice moraines: (1) to constrain the processes of sediment entrainment that lead to moraine formation, particularly whether it is warm or cold based and whether open system hydrologic conditions prevail; and (2) to constrain the age of the ice within the moraines and the transport times of the subglacial sediment. These objectives will aid assessments of these moraines as archives of Antarctica's glacial history.

\section{BACKGROUND}

The subglacial processes that entrain sediment in ice can alter the ice's oxygen and hydrogen stable isotope composition. When ice is melted and refrozen, heavier isotopes are preferentially retained, while lighter isotopes are preferentially mobile within the subglacial hydrologic system. Because of the larger mass difference, this effect occurs more strongly with oxygen than hydrogen isotopes, and the stable isotopes of debris-laden basal ice typically diverge from the $8: 1$ ratio of $\delta^{2} \mathrm{H}(\delta \mathrm{D})$ to $\delta^{18} \mathrm{O}$ that is seen in meteoric waters (Dansgaard, 1964).

Pioneering work on the stable isotopes of basal ice identified three subglacial behaviors that affect stable isotope composition: freezing in a closed system, freezing in an open system where the meltwater has a single source (e.g. only basal ice), and freezing in an open system where waters of multiple compositions are mixed (e.g. a mix of basal and surface meltwaters) (Jouzel and Souchez, 1982; Souchez and Jouzel, 1984; Souchez and de Groote, 1985). As meltwater refreezes, heavier isotopes will freeze first, causing the remaining meltwater to become progressively depleted. In an open system, water can enter and escape the refreezing site, with depleted meltwaters leaving the system as groundwater or through subglacial conduits. The escape of depleted subglacial water causes ice refreezing in an open system to be enriched in heavy isotopes compared with its source. In a closed system, meltwaters depleted of heavy isotopes are also refrozen, allowing for the formation of both basal ice layers that are enriched and basal ice layers that are depleted of heavy isotopes compared with the source ice (Fig. 1). In both the case of a closed system and an open system where meltwater comes from a single source, the basal ice isotopes will plot along a refreezing slope whose divergence from the meteoric waterline is determined by the abundance of heavy isotopes in the source ice (Jouzel and Souchez, 1982). Laboratory experiments have established the partition coefficients for heavy oxygen and hydrogen in the freezing process (Souchez and Jouzel, 1984; Lehmann and Siegenthaler, 1991; Iverson and Souchez, 1996). If the source composition is more depleted of heavy isotopes, the freezing slope is shallower; if it is enriched, the slope is steeper (Fig. 1). Refreezing of a mix of meltwaters of differing isotopic compositions can result in significant divergence from the theoretically predictable refreezing slope. The input of isotopically lighter waters (e.g. from surface melt) will steepen the refreezing slope; the input of isotopically heavier waters will make it less steep (Souchez and de Groote, 1985).

This framework has been used to interpret basal ice layers from alpine glaciers, the Greenland ice sheet, and Antarctic ice sheets. In temperate alpine glaciers, open system regelation is frequently documented in basal ice layers (e.g. Hubbard and Sharp, 1993). At many sites, distinct basal ice facies have different isotopic signatures. Laminated layers (associated with regelation processes) have the $\delta \mathrm{D}: \delta^{18} \mathrm{O}$ slopes predicted from freezing in a closed system or an

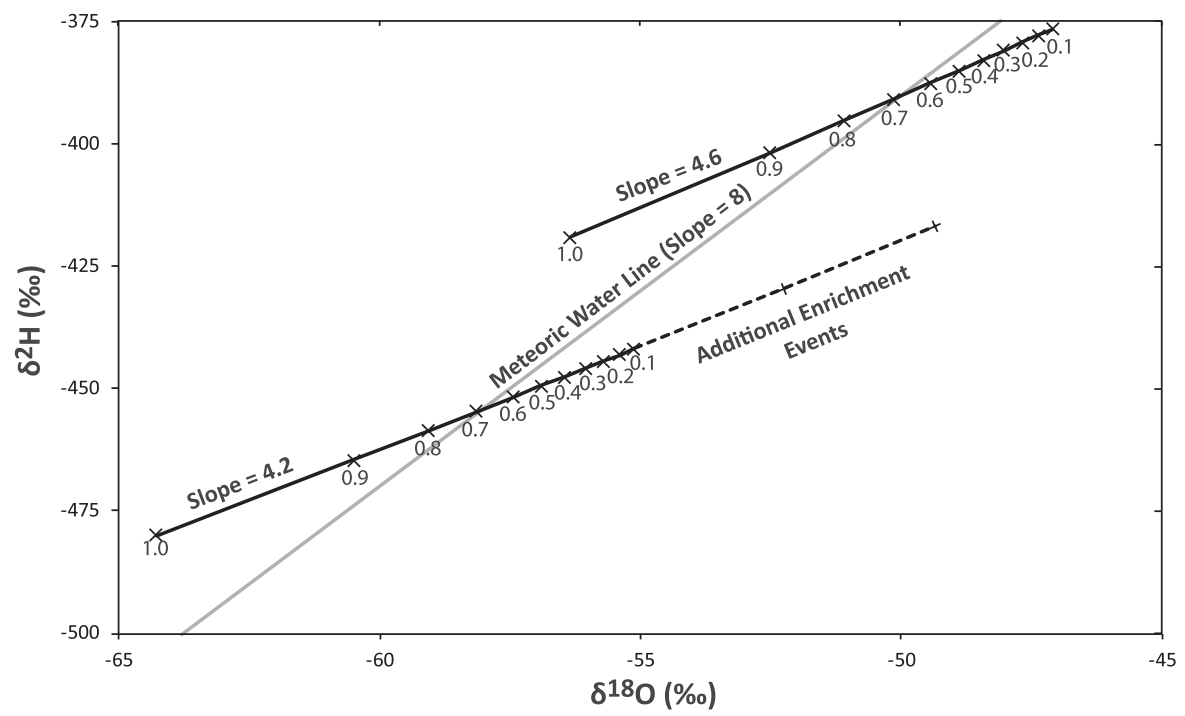

Fig. 1. Closed system theoretical freezing slopes (4.2 to 4.6) for initial meteoric water with initial two-isotope compositions of (-58\%o, $-454 \%$ ) and $(-50 \%,-390 \%$ o). Numbers reflect the fraction of the water that has frozen. The isotopic values of the remaining unfrozen water are plotted. Ice formed when $\sim<2 / 3$ of the water has frozen is enriched; the last $\sim 1 / 3$ of the refrozen ice is depleted. Thus, under open system refreezing where $>1 / 3$ of the melt is able to escape into the subglacial drainage, isotopic enrichment will be exclusively below the meteoric waterline. If the ice formed in a single refreezing event, enrichment of up to $2.9 \%$ o $\delta^{18} \mathrm{O}$ is possible. The maximum effect of two subsequent open system melt and freeze enrichment events is illustrated for the lower freezing slope. 
open system with a single source (i.e. Fig. 1). Dispersed layers (associated with freeze-on processes) have steeper co-isotopic slopes than theoretically expected from single source freezing and suggest input of surface meltwater (Hubbard and Sharp, 1995). Freeze-on processes also generally exclude air bubbles from the ice, whereas regelation-effected ice retains some of the original ice air content (Hubbard and Sharp, 1995). Some high arctic glaciers have greater $\delta \mathrm{D}: \delta^{18} \mathrm{O}$ slopes in basal ice than in surface snow, suggesting primarily freeze-on (Glasser and Hambrey, 2002), whereas others have basal isotopes consistent with closed system regelation (Gordon and others, 1988). Open system regelation without surface input is evidenced at several sites along the margin of the western Greenland ice sheet (Sugden and others, 1987; Knight, 1989). Other western Greenland sites have enrichment slopes that are too low to be explained by simple freezing, possibly due to the exchange of hydroxyls between meltwater and micas or clays (Souchez and others, 1990). Substantial isotopic enrichment is also observed in the silt-rich basal layers of Greenland ice cores (Johnsen and others, 1997); however in the GRIP core, no change in the co-isotopic slope is observed (Souchez and others, 1994). Similar isotopic enrichment without significant change in co-isotopic slope has been observed in basal ice layers at some Antarctic sites (lizuka and others, 2001). In cold-based ice that actively entrains sediment in the McMurdo Dry Valleys $\left(-17^{\circ} \mathrm{C}\right)$, no isotopic enrichment was observed nor any disturbance in ice gas content (Cuffey and others, 2000). It is likely that here the interfacial liquid responsible for debris entrainment acted as a closed system in such a way that no isotopic differentiation occurred. By contrast, Adelie Land cores with basal temperatures of $-7.5^{\circ} \mathrm{C}$ have isotope slopes that are consistent with closed system refreezing (Tison and others, 1993). Debris apron entrainment at the margins of polar glaciers has a coisotopic signature consistent with refreezing of meltwater mixed with meteoric ice that never melted (Fitzsimons and others, 2008).

Stable isotopes of ice are more frequently employed as temperature proxies than as tracers of subglacial processes and are one of the primary tools used in constructing climate records from ice cores. Large differences in both $\delta \mathrm{D}$ and $\delta^{18} \mathrm{O}$ are observed between Holocene and Pleistocene periods in ice cores from Greenland and Antarctica, as well as between interstadial and stadial phases of the Pleistocene (e.g. Petit and others, 1999; Johnsen and others, 2001). In East Antarctica, the stable isotope signatures of past periods are known from ice cores taken in both the interior and at the margins of the continent; Holocene $\delta \mathrm{D}$ values vary from -200 to $-440 \%$ with altitude and distance from the coast (Masson and others, 2000). At the interior highelevation sites (such as Vostok, Dome Fuji, Dome C and Dome B), ice from Last Glacial Maximum (LGM) is $~ 40 \%$ depleted of deuterium compared with the Holocene; less extreme Pleistocene interstadials (such as oxygen isotope stage 3) are approximately halfway between Holocene and LGM values (Jouzel and others, 1995; Petit and others, 1999; Uemura and others, 2012). When glacial ice originates as surface snow, the altitude, continentality and temperature of the location where the ice initially formed control stable isotope values. If we can account for the effects of subglacial processes, we can reconstruct the environmental conditions under which basal ice initially formed. We can, therefore, use the stable isotopes of basal ice layers to determine whether the ice is sourced locally or from the high-elevation continental interior and whether it dates from Holocene, LGM, or pre-LGM periods. The time and location of ice formation set an upper bound for the time and location of sediment entrainment.

\section{FIELD SITE AND METHODS}

Ice samples were collected beneath and adjacent to the Mount Achernar moraine $\left(84.2^{\circ} \mathrm{S}, 161^{\circ} \mathrm{E}\right)$ during December 2015. This site is located in the central Transantarctic Mountains, on the south side of Law Glacier, near where ice first emerges off the polar plateau (Fig. 2). In this region of Antarctica, mean annual surface temperatures average $-40^{\circ} \mathrm{C}$ and annual snow accumulation are $<40 \mathrm{~mm} \mathrm{a}^{-1}$ w. e. (Scarrow and others, 2014). A $70-80 \mathrm{~mW} \mathrm{~m}^{-2}$ geothermal heat flux is modeled for the region, and ice thermodynamics suggest that warm-based ice occurs where ice thickness is $\geq 1000-1500 \mathrm{~m}$ (Pattyn, 2010; Van Liefferinge and Pattyn, 2013). Along the blue ice moraine, the ice thickness of Law Glacier is not known in detail but likely varies between 800 and $1200 \mathrm{~m}$ (Fretwell and others, 2013). Patches of warm-based ice are suggested in the thicker regions of Law Glacier by the Pattyn (2010) model. Conditions that definitively indicate warm-based conditions occur $\sim 30 \mathrm{~km}$ upstream of Mount Achernar Moraine, around the divide between the Law and Marsh Glaciers on the polar plateau (Pattyn, 2010). The variation in basal conditions along flowline means that sediment emerging from Law Glacier might be entrained through either cold-based mechanisms such as sediment shearing and interfacial effects or warm-based mechanisms such as regelation and freeze-on.

The blue ice moraine at the base of Mount Achernar has a core of glacier ice hundreds of meters thick, which is fed by upward-flowing ice from the Law Glacier (Kassab and others, 2016). Here, sediment emerges through the sublimation of the underlying ice (Bader and others, 2017). Most of the moraine exhibits a structure of parallel ridges that follow the modern glacial margin, with ridge widths of 50-100 m and narrower troughs. Sediment cover is thicker in the ridges, suggesting that they are related to regions of greater sediment flux from the ice below. Cosmogenic isotopes indicate the oldest parts of the moraine have had at least several hundred ka of surface exposure, perhaps $>500 \mathrm{ka}$ and allow us to divide the moraine into distinct sections exposed during the Holocene, LGM and pre-LGM (Kaplan and others, 2017) (Fig. 2). The different aged portions of the moraine differ in pebble lithology, geomorphology and degree of chemical weathering (Bader and others, 2017). The sediment becomes thicker away from the moraine-ice margin, with debris ranging from a few centimeters thick near the margin to $>1 \mathrm{~m}$ thick in the oldest parts of the moraine (Scarrow and others, 2014). In the Holocene section of the moraine, sediment cover is $<5 \mathrm{~cm}$ thick and is unoxidized. The LGM section has sediment thicknesses of $5-25 \mathrm{~cm}$. Pre-LGM sections have exposure ages of $>100 \mathrm{ka}$, a topographically muted ridge, and trough structure, and sediment depths generally $>50 \mathrm{~cm}$. In the Holocene-aged portions of the moraine, the topography is broken up by flat areas of clear ice that appear to be melt ponds (Fig. 2). During the warmest field days in December 2015 , the melt was observed in this portion of the moraine 


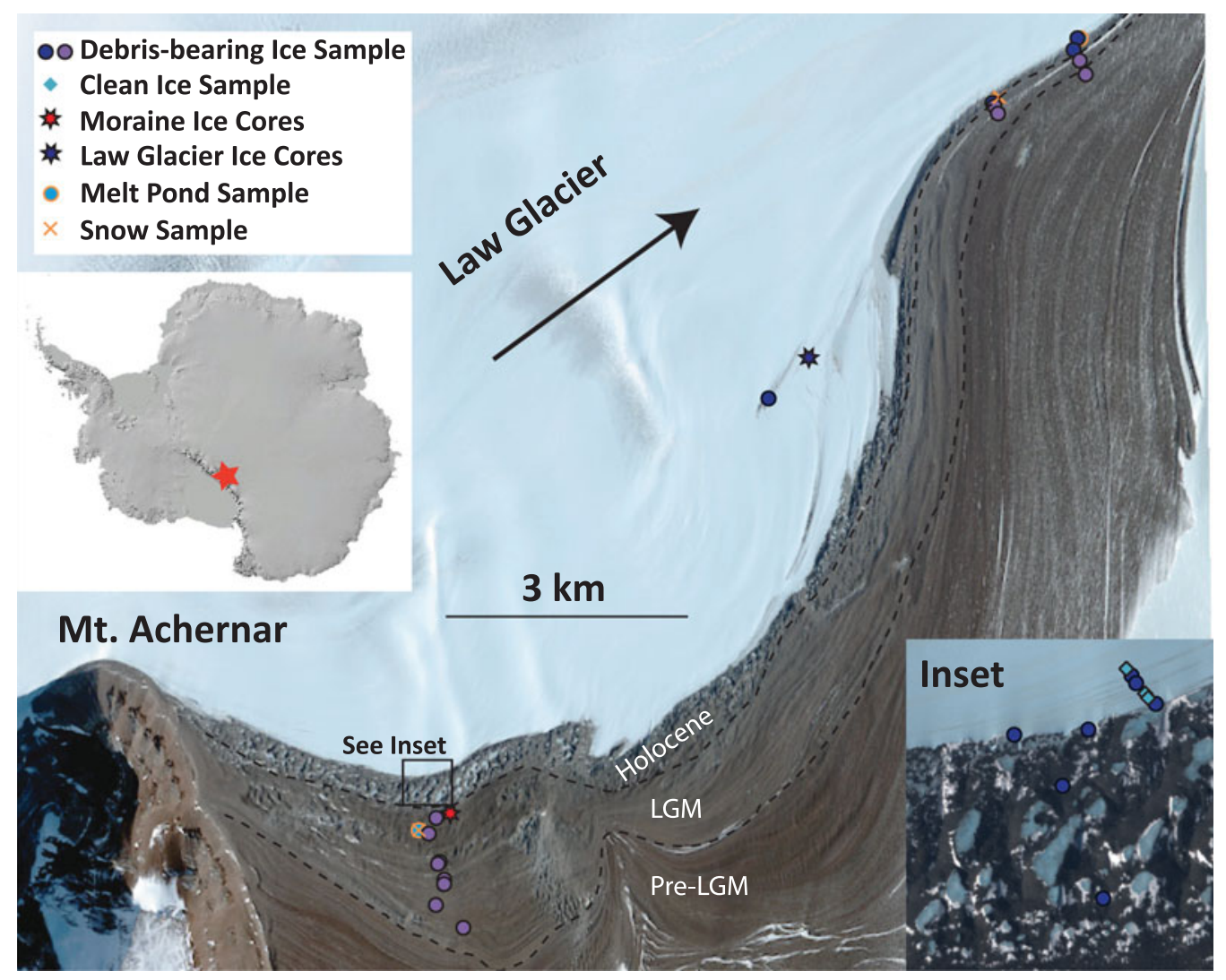

Fig. 2. Location of ice samples on Mount Achernar Moraine. The transect of samples collected in the upper right of the inset is courtesy of ANSMET. Imagery is a 2014 worldview2 file courtesy of Polar Geospatial Center.

where sediment is thinnest, enabled by the absorption of energy by dark sediment even while air temperatures were below freezing. Such ponds occur with diminishing frequency in the LGM-aged portions of the moraine, where they are depressed below the moraine surface by tens of meters and are absent from the oldest portions of the moraine.

Several types of ice samples were collected from the Mount Achernar Moraine: two sets of shallow ice cores and ice surface samples collected along horizontal transects (i.e. along moraine surface) through the Holocene and LGM portions of the moraine (Fig. 2). Three horizontal transects were sampled, one in the widest portion of the moraine and two in the moraine's downstream tail. The horizontal transect samples were collected by shoveling away overlying sediment and breaking up the ice below with an axe. Axedoff pieces were immediately placed in Nasco Whirl-Pak bags, allowed to completely melt and then transferred to $20 \mathrm{~mL}$ tubes of borosilicate glass. The transects did not extend into the pre-LGM sections of the moraine, as the sediment cover was prohibitively thick. Six ice samples collected in January 2012 by an Antarctic Search for Meteorites (ANSMET) team were also included in the analysis. These samples were collected from the transition between the clean ice and the moraine and include three debris band samples, two clean ice samples and one sample that contains a thin debris band in otherwise clean ice. The ANSMET samples were collected by extracting $0.125 \mathrm{~m}^{3}$ blocks of ice with steel chisels. The ANSMET samples were kept cold and then melted under laboratory conditions on return from the field. Additionally, we collected two samples of snow and three samples of ice from frozen melt ponds
(Fig. 2). The goals in these collections were to test whether the moraine ice or the melt ponds could have formed from local snow and to test if the melt ponds develop a unique isotopic signature.

Shallow, 3" $(7.5 \mathrm{~cm})$ diameter ice cores were collected from two locations. One location is in an area of Law Glacier outside the main body of the moraine, where debris bands reach the surface of otherwise clean ice; the other location is in the LGM section of the main body of the moraine, $\sim 500 \mathrm{~m}$ in from the moraine's boundary with clean ice (Fig. 2). The Law Glacier location is also in a blue ice area but lacks substantial debris accumulation. It is possible that the emergence of the debris band is recent or that accumulated debris was removed by active glacier processes. At the Law Glacier location, two ice cores were collected; at the moraine location, three ice cores were collected. Ice cores were collected by hand auger to depths of $50-180 \mathrm{~cm}$. Ice was first photographed and then immediately transferred to an insulated storage system where it was not allowed to melt until it reached a laboratory setting. In the laboratory, the cores were sectioned, split and analyzed for sediment and bubble content. On the ends of core sections, gas bubble presence and morphology were captured by light microscopy at the Crary Laboratory in McMurdo Station. Semi-cylindrical sections of core were melted and filtered so that ice density and sediment content could be assessed. Separate splits were allowed to completely melt and were transferred to $20 \mathrm{~mL}$ plastic containers for stable isotope analysis.

At Indiana University Purdue University Indianapolis, the stable isotope samples were centrifuged in an Eppendore Centrifuge 5810 for $10 \mathrm{~min}$ each to remove any sediment. 
(In most cases, little or no sediment was removed by this process.) The samples were then transferred into vials and analyzed by a Picarro L2130-i cavity ringdown spectrometer (isotopic water analyzer) equipped with A0211 vaporization module. The ratio of ${ }^{18} \mathrm{O}$ to ${ }^{16} \mathrm{O}$ and of deuterium to protonium was determined in ppm in relation to Vienna Standard Mean Ocean Water (VSMOW). Results were corrected for memory, drift and offset from the VSMOW scale using a low (-54.55\%; USGS49), mid-range (-13.39\%; Picarro 3C), and high standard (12.34\%; Picarro ER1) following the methods of Geldern and Barth (2012).

\section{RESULTS}

\subsection{Ice bubbles and sediment textures}

The sediment in the Mount Achernar Moraine ice cores is 'clotted', with most sediment occurring in 1-5 mm irregular spheres. Similar clots have been described in the upper portions of the basal ice layer of the Greenland ice sheet (e.g. Knight and others, 1994) and in the offshore record of Antarctica (Cowan and others, 2012; Licht and Palmer, 2013). The total sediment load in the cores is generally $<2 \%$ sediment by weight (Table 1 ). The two ice core sites differ appreciably in the distribution of the sediment clots. The debris band in the Law Glacier ice cores is $\sim 5 \mathrm{~cm}$ wide and dips at an $85^{\circ}$ angle with respect to the ice

Table 1. Ice core samples

\begin{tabular}{|c|c|c|c|c|c|}
\hline & $\begin{array}{l}\text { Ice } \\
\text { core }\end{array}$ & $\begin{array}{l}\text { Depth } \\
\mathrm{cm}\end{array}$ & $\begin{array}{c}\delta^{18} \mathrm{O} \\
\% \text { o }\end{array}$ & $\begin{array}{c}\delta^{2} \mathrm{H} \\
\% \text { o }\end{array}$ & $\begin{array}{l}\text { Sediment } \\
\text { weight \% }\end{array}$ \\
\hline \multirow{24}{*}{$\begin{array}{l}\text { Site } 1(-84.1410, \\
161.6896)\end{array}$} & 1 & 0 & -52.75 & -414.79 & 0.75 \\
\hline & 1 & 8 & -51.73 & -408.15 & 0.46 \\
\hline & 1 & 17 & -53.00 & -416.65 & 0.54 \\
\hline & 1 & 29 & -53.02 & -416.12 & 0.20 \\
\hline & 1 & 43 & -52.99 & -415.34 & 0.13 \\
\hline & 1 & 53 & -53.16 & -415.71 & $\mathrm{NA}$ \\
\hline & 1 & 70 & -53.27 & -416.43 & NA \\
\hline & 1 & 85 & -53.05 & -415.11 & NA \\
\hline & 1 & 90 & -52.62 & -412.05 & NA \\
\hline & 1 & 97 & -53.39 & -417.53 & $\mathrm{NA}$ \\
\hline & 1 & 130 & -52.04 & -408.35 & NA \\
\hline & 2 & 0 & -52.41 & -413.09 & 0.33 \\
\hline & 2 & 10 & -52.42 & -411.82 & 0.39 \\
\hline & 2 & 21 & -53.00 & -417.32 & 0.43 \\
\hline & 2 & 31 & -52.22 & -411.75 & 0.66 \\
\hline & 2 & 43 & -52.32 & -413.43 & 0.48 \\
\hline & 2 & 56 & -51.35 & -403.59 & 0.84 \\
\hline & 2 & 70 & -52.37 & -411.59 & 0.45 \\
\hline & 2 & 84 & -51.88 & -408.83 & 1.41 \\
\hline & 2 & 98 & -50.43 & -398.65 & 0.40 \\
\hline & 2 & 110 & -51.32 & -403.28 & 0.36 \\
\hline & 2 & 121 & NA & NA & 0.34 \\
\hline & 2 & 134 & -51.91 & -407.29 & 0.17 \\
\hline & 2 & 149 & -52.10 & -409.65 & 0.24 \\
\hline \multirow{11}{*}{$\begin{array}{c}\text { Site } 2(-84.1879 \\
\quad \mathrm{N}, 161.2882 \mathrm{E})\end{array}$} & 3 & 7 & -56.10 & -443.58 & NA \\
\hline & 4 & 0 & -52.20 & -423.17 & NA \\
\hline & 4 & 8 & -52.88 & -422.73 & $\mathrm{NA}$ \\
\hline & 4 & 28 & -55.35 & -437.29 & 0.07 \\
\hline & 4 & 43 & -55.20 & -435.61 & 2.03 \\
\hline & 4 & 57 & -55.00 & -432.91 & 0.01 \\
\hline & 5 & 0 & -54.96 & -435.08 & 0.38 \\
\hline & 5 & 10 & -55.34 & -437.01 & 0.76 \\
\hline & 5 & 24 & -55.69 & -439.06 & 0.06 \\
\hline & 5 & 43 & -55.36 & -435.35 & 0.00 \\
\hline & 5 & 61 & -54.30 & -428.72 & 0.01 \\
\hline
\end{tabular}

surface. The clots are fairly evenly distributed within in this debris-bearing zone. The moraine ice cores collected contain several separate thin debris bands, $\sim 1 \mathrm{~cm}$ thick and dipping $30-60^{\circ}$ from the ice surface. These discrete bands bear all of the ice cores' sediment, matching the description of laminated basal ice (Knight, 1994). The Law Glacier ice cores bear several healed cracks or shear planes that are not observed in the cores from the moraine.

All the sampled ice is bubble-rich, but with considerable variation in the bubble size, morphology and distribution. Bubble morphologies include: spherical forms 250-750 $\mu \mathrm{m}$ in diameter, spherical forms $\sim 25-75 \mu \mathrm{m}$ in diameter, elongate forms and irregular forms (Fig. 3). The bimodal distribution of spherical bubbles has been previously observed in Antarctic ice forming from firn (Lipenkov, 2000). In some locations within the core, bubbles line up as planar features; in others, the bubbles are uniformly distributed. In some sections, the elongate bubbles appear to be oriented as a metamorphic texture, deforming around sediment clots and aligning toward ice crystal orientation. Sediment clots are not in or adjacent to bubbles.

Several of the photographed samples also contain vapor figures - thin hexagonal prisms 500-1000 $\mu \mathrm{m}$ in diameter and $<100 \mu \mathrm{m}$ in width. Vapor figures are water vapor-filled negative crystals formed from the melting and refreezing of crystalline ice under conditions where a thermal gradient allows faster refreezing on one side of the crystal (Nakaya, 1956). Vapor figures migrate along thermal gradients as the ice refreezes, often elongating, deforming or splitting them into minute droplets (Nakaya, 1956). Evidence of such thermal migration is demonstrated in several of the ice core photographs (Fig. 3). The vapor figures could also be interpreted as hexagonal voids formed during the mechanical
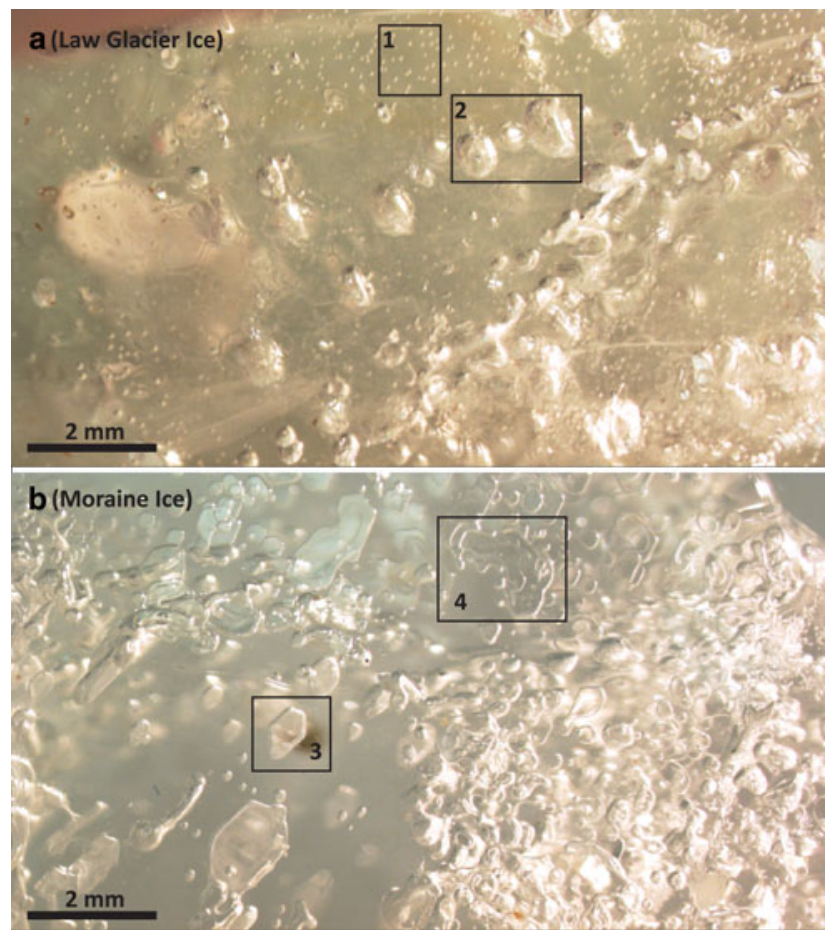

Fig. 3. Exemplar photographs of the bubble patterns in ice cores from Law Glacier (a) and beneath the moraine (b). Key features are: (1) Small bubbles, (2) Large bubbles, (3) Vapor figures, and (4) Vapor figures with evidence of thermal migration. Bimodal bubble distribution is evident in the photo (a); Vapor figures and large bubbles are abundant in the photo (b). 
relaxation of the ice, such as are seen when ice cores are brought up from depths $>1000 \mathrm{~m}$ (Gow, 1971). However, such voids form on a far smaller scale $(<300 \mu$ m diameter $)$ and lack the thermal migration features that we observe.

There are substantial differences in the distribution of bubble and vapor figure morphologies between the Law Glacier ice cores (Fig. 3a) and the moraine ice cores (Fig. 3b). The moraine ice cores have abundant vapor figures; whereas vapor figures are nearly absent from the Law Glacier ice cores. The Law Glacier ice has a greater abundance of spherical bubbles, particularly of smaller size. This is consistent with substantial melt and refreezing occurring in the morainal ice and greater preservation of original glacial ice in the debris bands of the Law Glacier ice.

\subsection{Isotope data}

Stable isotope values from the study area range from -59 to $-47 \%$ o $\delta^{18} \mathrm{O}$ and from -375 to $-465 \%$ o $\delta \mathrm{D}$ (Fig. 4). The ice isotopes plot in two distinct groups: One group (group A) consists of the shallow ice cores on Law Glacier and the 2012 ANSMET samples collected in clean ice. The other (group B) consists of all the moraine ice core samples, all of the samples of bulk ice collected from the moraine proper and the 2012 ANSMET samples collected in debris bands emerging from Law Glacier immediately adjacent to the moraine (Fig. 2). The $\delta \mathrm{D}: \delta^{18} \mathrm{O}$ slope of group $\mathrm{A}$ is 6.69 \pm 1.39 (S.E.); the slope of the group B is $5.35 \pm 0.92$ (S.E.). Theoretical refreezing slopes range from 4.2 to 4.6 for the isotopic values found in the study area (Fig. 1). Both slopes are steeper than would be expected for simple refreezing of a single reservoir. However, the group B slope is within the standard error of the theoretical refreezing slopes, whereas the group A data cannot be explained by refreezing of ice of consistent initial composition.

Both the Holocene aged and Pleistocene aged portions of the moraine (surface exposure ages in Kaplan and others, 2017) plot along the same enrichment trend, suggesting that the source ice has similar isotopic compositions for both (Fig. 4, Tables 1 and 2). However, the ice in the
Pleistocene aged portion of the moraine is consistently more isotopically enriched than the ice in the Holocene aged portion. Because the ice samples from the Pleistocene section of the moraine are more enriched in heavy isotopes from the meteoric waterline than the $2.9 \% \delta^{18} \mathrm{O}$ theoretically possible from a single refreezing event (Fig. 1), progressive enrichment events are strongly suggested.

The melt-pond ice plots along the same trend as the surrounding moraine ice (Fig. 4). Ponds may, therefore, experience relatively little isotope loss in their formation. The snow samples are isotopically enriched compared with any of the sampled ice; this comparison suggests that neither the melt ponds, nor the ice underlying the moraine, nor the clean ice in Law Glacier are formed from local snow.

Within the shallow ice cores, isotopic variability with depth differs substantially between the two sampling sites. In the cores from the moraine, ice is in general increasingly enriched in heavy isotopes toward the surface (Fig. 5). However, these cores also feature sediment bands in their upper sections that are absent from lower portions and only contain five measurements in total. In the Law Glacier cores, enrichment excursions occur in individual subsamples, but these values generally return to previous values adjacent to the enriched sample (Fig. 5). The isotopic excursions in the Law Glacier cores occur at the locations with healed cracks or shear planes in the ice.

\section{DISCUSSION}

\subsection{Mechanism of debris entrainment}

Nearly all of the sampled sediment-bearing ice of Law Glacier and Mount Achernar Moraine is enriched in ${ }^{18} \mathrm{O}$ and depleted in deuterium excess compared with meteoric water and conversely, no sample is significantly depleted in ${ }^{18} \mathrm{O}$ or enriched in deuterium excess compared with meteoric water. This pattern of enrichment suggests that not all the basal melt has refrozen in a closed system and that meltwater was lost to the subglacial hydraulic system (open

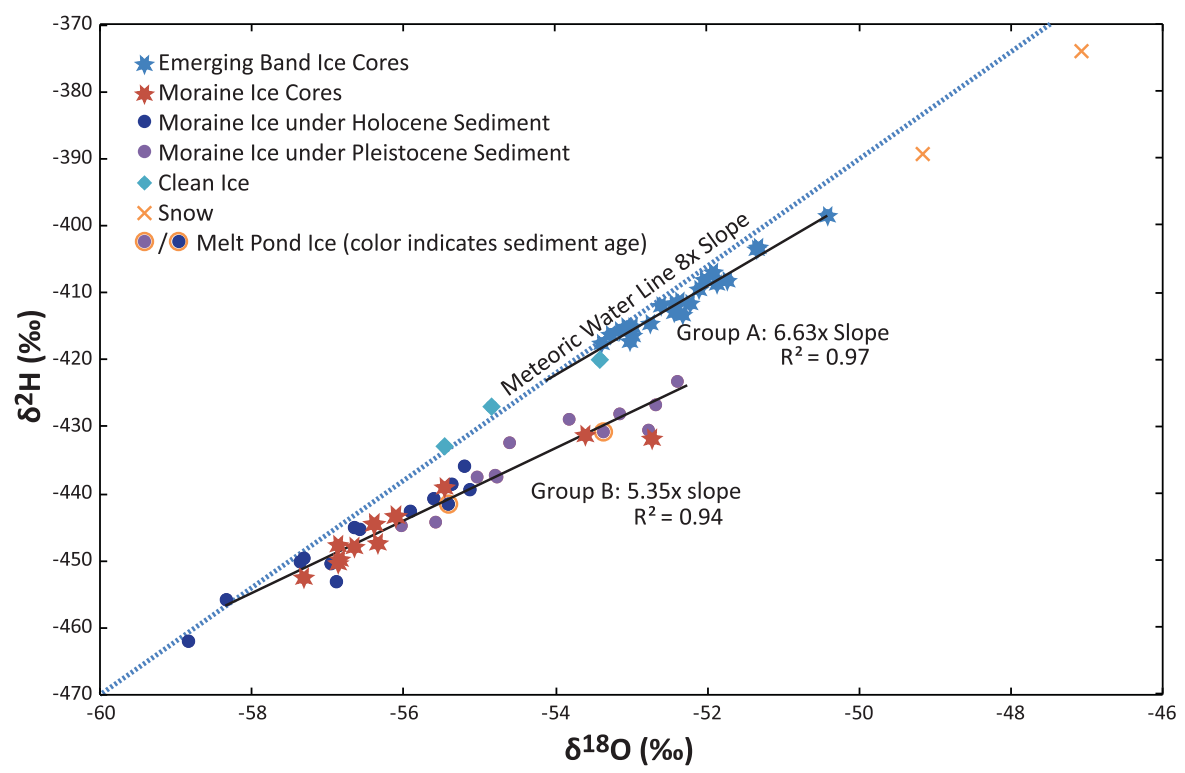

Fig. 4. Co-isotope plot depicting enrichment slopes from the global meteoric waterline. All analytical uncertainties are well within symbol size. Group A consists of the clean ice samples and samples from the Law Glacier ice cores. Group B consists of moraine ice samples and samples from the moraine ice cores. For group B in particular, the data are similar to results expected theoretically for regelation in an open system (Fig. 1). Also, local snow is isotopically enriched compared to any of the ice samples. 
Table 2. Bulk ice samples

\begin{tabular}{|c|c|c|c|c|c|c|}
\hline & Sample & Latitude & Longitude & Sediment Age & $\begin{array}{c}\delta^{18} \mathrm{O} \\
\% \text { o }\end{array}$ & $\begin{array}{c}\delta^{2} \mathrm{H} \\
\% о\end{array}$ \\
\hline \multirow[t]{14}{*}{ Main Moraine Transect } & $\mathrm{OA}$ & -84.1819 & 161.2706 & Holocene & -56.57 & -445.48 \\
\hline & OC-A & -84.1411 & 161.6867 & Holocene & -55.61 & -440.91 \\
\hline & OC-B & -84.1411 & 161.6867 & Holocene & -55.36 & -438.66 \\
\hline & $\mathrm{OE}$ & -84.1818 & 161.2627 & Holocene & -57.36 & -450.27 \\
\hline & $1 \mathrm{~A}$ & -84.1828 & 161.2677 & Holocene & -55.21 & -436.03 \\
\hline & $2 \mathrm{~A}$ & -84.1881 & 161.2677 & LGM & -55.59 & -444.42 \\
\hline & $2 \mathrm{C}$ & -84.1867 & 161.2762 & LGM & -55.04 & -437.52 \\
\hline & 2-3 POND & -84.1896 & 161.2728 & LGM & -53.37 & -430.83 \\
\hline & $3 \mathrm{~A}$ & -84.1931 & 161.2875 & LGM & -56.03 & -444.72 \\
\hline & $3 B$ & -84.1928 & 161.2878 & LGM & -53.83 & -428.94 \\
\hline & $3 C$ & -84.1907 & 161.2819 & LGM & -52.68 & -426.84 \\
\hline & $3 \mathrm{D}$ & -84.1909 & 161.2797 & LGM & -53.16 & -428.30 \\
\hline & $3 \mathrm{~F}$ & -84.1970 & 161.3123 & LGM & -54.79 & -437.37 \\
\hline & 2-3 SNOW & -84.1896 & 161.2728 & $\mathrm{NA}$ & -47.06 & -374.01 \\
\hline \multirow[t]{10}{*}{ Downstream Transects } & 1F POND & -84.1155 & 161.9096 & Holocene & -55.43 & -441.53 \\
\hline & 1H POND & -84.1070 & 162.0514 & Holocene & -55.42 & -441.72 \\
\hline & 1F CREST 1 & -84.1154 & 161.9071 & Holocene & -55.14 & -439.40 \\
\hline & 1F CREST 2 & -84.1157 & 161.9097 & Holocene & -56.97 & -450.48 \\
\hline & $1 \mathrm{G}$ & -84.1076 & 162.0501 & Holocene & -55.92 & -442.59 \\
\hline & $1 \mathrm{H}$ & -84.1070 & 162.0514 & Holocene & -58.85 & -462.04 \\
\hline & 1F OUT & -84.1170 & 161.9132 & LGM & -52.76 & -430.66 \\
\hline & $1 \mathrm{G}$ R/G & -84.1082 & 162.0547 & LGM & -54.77 & -437.53 \\
\hline & 1G OUT & -84.1090 & 162.0613 & LGM & -54.60 & -432.44 \\
\hline & 1F SNOW & -84.1155 & 161.9096 & NA & -49.16 & -389.26 \\
\hline \multirow[t]{4}{*}{ ANSMET Transect } & Sample 1 & -84.1816 & 161.2814 & Emerging & -56.65 & -445.12 \\
\hline & Sample 2 & -84.1813 & 161.2809 & Clean Ice & -53.41 & -420.01 \\
\hline & Sample 3 & -84.1812 & 161.2806 & Emerging & -57.31 & -449.61 \\
\hline & Sample 4 & -84.1810 & 161.2799 & Emerging & -58.34 & -455.89 \\
\hline
\end{tabular}

system) (Fig. 1). Therefore, our primary hypothesis is that regelation in an open subglacial hydraulic system is responsible for the entrainment of the sediment that supplies Mount Achernar Moraine. An alternative explanation is that interfacial processes in cold-based ice entrained the sediment and that the isotope enrichment occurred when the ice reaches the surface, with light isotopes lost to evaporation or sublimation. Another alternative hypothesis is that exchange between meltwater and isotopes and hydroxyls on micas or clays is the primary cause of isotope enrichment. However, the slope of the group B samples is most consistent with our primary hypothesis (open system regelation). For the group A samples, the slope is too steep for open system regelation alone and mechanisms involving cold-based processes are more plausible.

The ice core internal structures are useful in elucidating the presence of melting and re-freezing processes during sediment entrainment (distinguishing between our primary and alternative hypotheses). The vapor figures that are abundant in the moraine ice core samples form from the internal melting and re-freezing of ice crystals (Fig. 3). If the sediment were entrained through cold-based processes, the morainal ice still must have been at the melting point during at least some portion of its history to produce the vapor figures. The Law Glacier ice cores have far fewer vapor figures in the photomicrographs (Fig. 3a) and less influence of isotopic enrichment than group B (Fig. 4). At that location, some or all of the sediment entrainment may have occurred through cold-based processes. The enrichment occurring primarily along cracks (Fig. 5) is consistent with a shearing mechanism for sediment entrainment that could have been cold-based (Tison and others, 1993). It is also possible that meltwater refroze together with unaffected meteoric ice to form an intermediate slope (Fitzsimons and others, 2008).

The sublimation-driven mass loss in the blue ice area and the presence of surface melt ponds in the moraine motivates consideration of surface mass loss as a cause of isotopic enrichment. Though sublimation and melt do not cause isotopic fractionation (Moser and Stichler, 1980), loss to evaporation before refreezing or partial refreezing of the sublimate can both cause isotopic enrichment and divergence from the meteoric waterline. Enrichment from the partial freezing of sublimate has been documented in snow and firn (Stichler and others, 2001; Sokratov and Golubev, 2009). However, such effects are not generally observed in solid ice, as the sublimating surface does not have the porosity necessary to trap and refreeze the sublimate (Moser and Stichler, 1980; Sokratov and Golubev, 2009). And though the composition of the surface melt ponds plots along the same enrichment trend as other ice samples, the texture of the bulk ice and ice core samples is very different from those of the melt ponds. Original, spherical air bubbles are preserved in the nonpond ice, as are sediment clots. Both of these features are disturbed by bulk refreezing processes and are absent from the melt pond samples. Contrastingly, the retention of clots and bubbles has been documented in the regelation enrichment process (Hubbard and Sharp, 1995). Furthermore, enrichment is seen at depth in the ice cores (Fig. 5), well below the influence of surface melt 

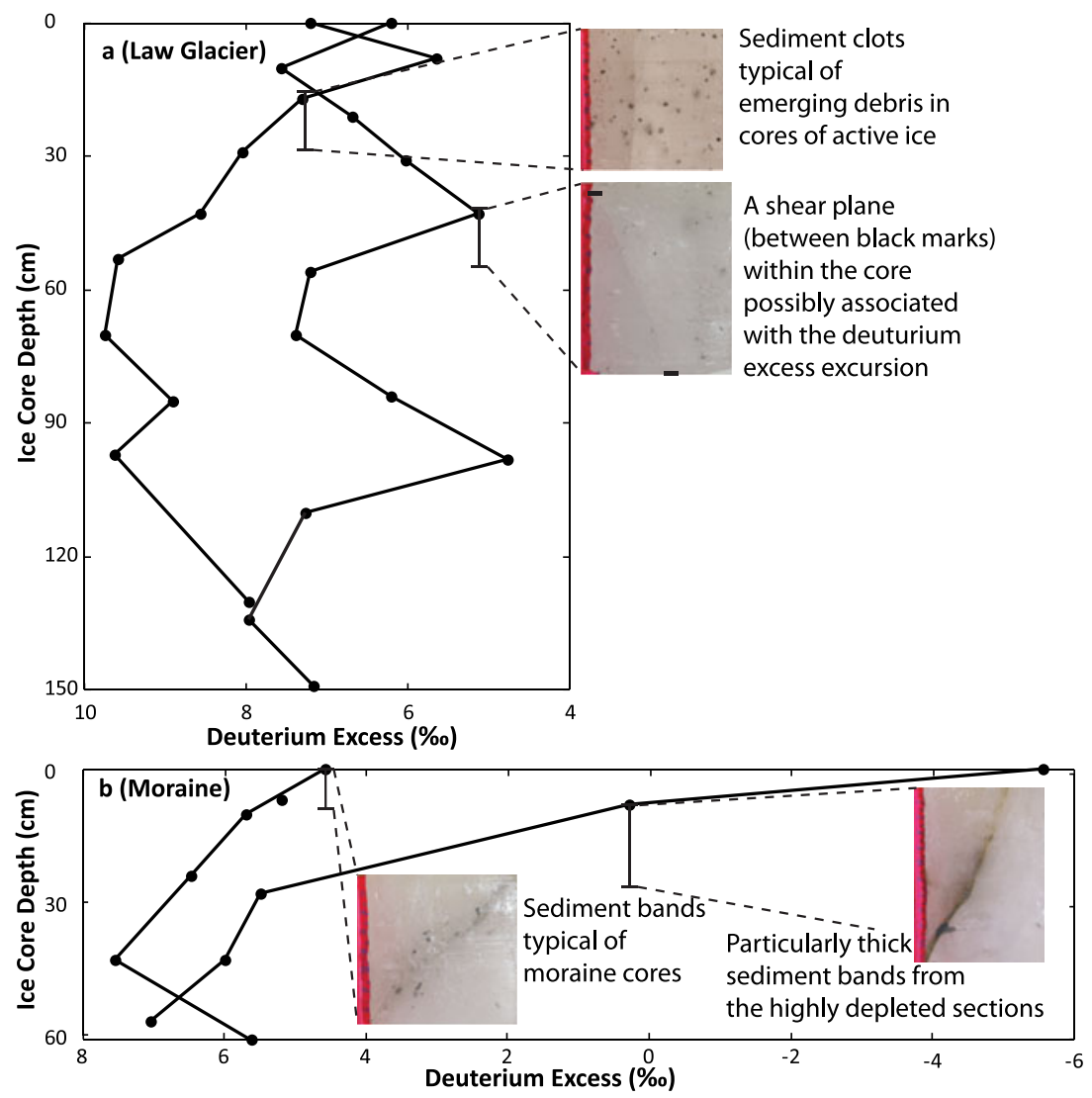

Fig. 5. Deuterium excess with depth in (a) the Law Glacier ice cores; (b) the moraine ice cores. The excursions in the Law Glacier cores (a) correspond to shear planes in the ice. The large excursion in the moraine cores (b) corresponds to a sediment-rich section.

or sublimation. We, therefore, consider substantial evaporation or sublimation enrichment unlikely for either of the isotope groups.

The exchange between meltwater and hydroxyl-bearing sediment also fails to explain the variation within the ice cores. Under that hypothesis, we would expect to see the greatest enrichment in samples with the highest sediment load. Instead, large isotopic excursions are seen below cracks or shear planes in the ice (Fig. 5). Furthermore, isotope enrichment from hydroxyls produces enrichment slopes far below those predicted theoretically for regelation enrichment (Souchez and others, 1990). Contrastingly, the slopes of the two isotope groups are either slightly or significantly larger than theoretical regelation enrichment slopes.

Hence, the only hypothesis consistent with the isotope and ice texture data are that sediment in the main part of Mount Achernar Moraine was entrained through warmbased processes, such as regelation (Figs 1 and 4). Alternative mechanisms of isotope enrichment (such as surface melting and exchange on hydroxyls) do not explain the ice textures or the isotope data. The group $\mathrm{A}$ data (clean ice and the Law Glacier ice cores) did not plot along a regelation enrichment slope, so it is conceivable that cold-based processes with little isotopic effect were responsible for sediment entrainment at the Law Glacier ice core location, with enrichment along cracks and shear planes. It is also conceivable that a reservoir of isotopically heavier water was also mixing into the Law Glacier ice core samples during open system subglacial freezing (Souchez and de Groote, 1985). However, the presence of air bubbles in the group A ice core suggests against bulk freeze-on. There may, therefore, be a mix of thin segments of refrozen ice and meteoric ice in group A (and possibly to a lesser extent in group B), as has been observed at some marginal sites (Fitzsimons and others, 2008).

\subsection{Moraine ice origin}

The ice underlying Mount Achernar Moraine is almost certainly sourced from the polar plateau and does not originate locally in the Transantarctic Mountains. Local snow is far more isotopically enriched than any of the ice (Fig. 4). Furthermore, the Dominion Range Ice Core, located $~ 100$ $\mathrm{km}$ from the site, has Holocene $\delta^{18} \mathrm{O} \sim-41 \%$ and LGM values $\sim-46 \%$ (Mayewski and others, 1990) - well enriched in heavy oxygen from the values found in the moraine ice, which are below $-50 \%$ (Fig. 6). Even at the South Pole, $600 \mathrm{~km}$ toward the interior of the continent from the Mount Achernar site, 20th-century snow values are $\sim-400 \% \delta \mathrm{D}$ (Jouzel and others, 1983), enriched compared with any Mount Achernar ice sample (Fig. 6).

We can assess the original isotopic composition of the ice prior to any alteration by subglacial processes by examining the intersection of the trendlines within the isotope groups (A and $\mathrm{B}$ ) with the meteoric waterline. Both these intersection points are similar to isotope values found in the deep interior of the polar plateau (Fig. 6). The enrichment trend in group A intersects the meteoric waterline at $\sim \delta^{18} \mathrm{O}=-54.6 \%$, $\delta \mathrm{D}=-427 \%$. These values are comparable with Holocene values found at Dome Fuji $(3810 \mathrm{~m})$ (Uemura and others, 2012), the oxygen isotope stage (OIS) 5a/5c and OIS 3 values found at Dome C (3233 m) (Augustin and others, 


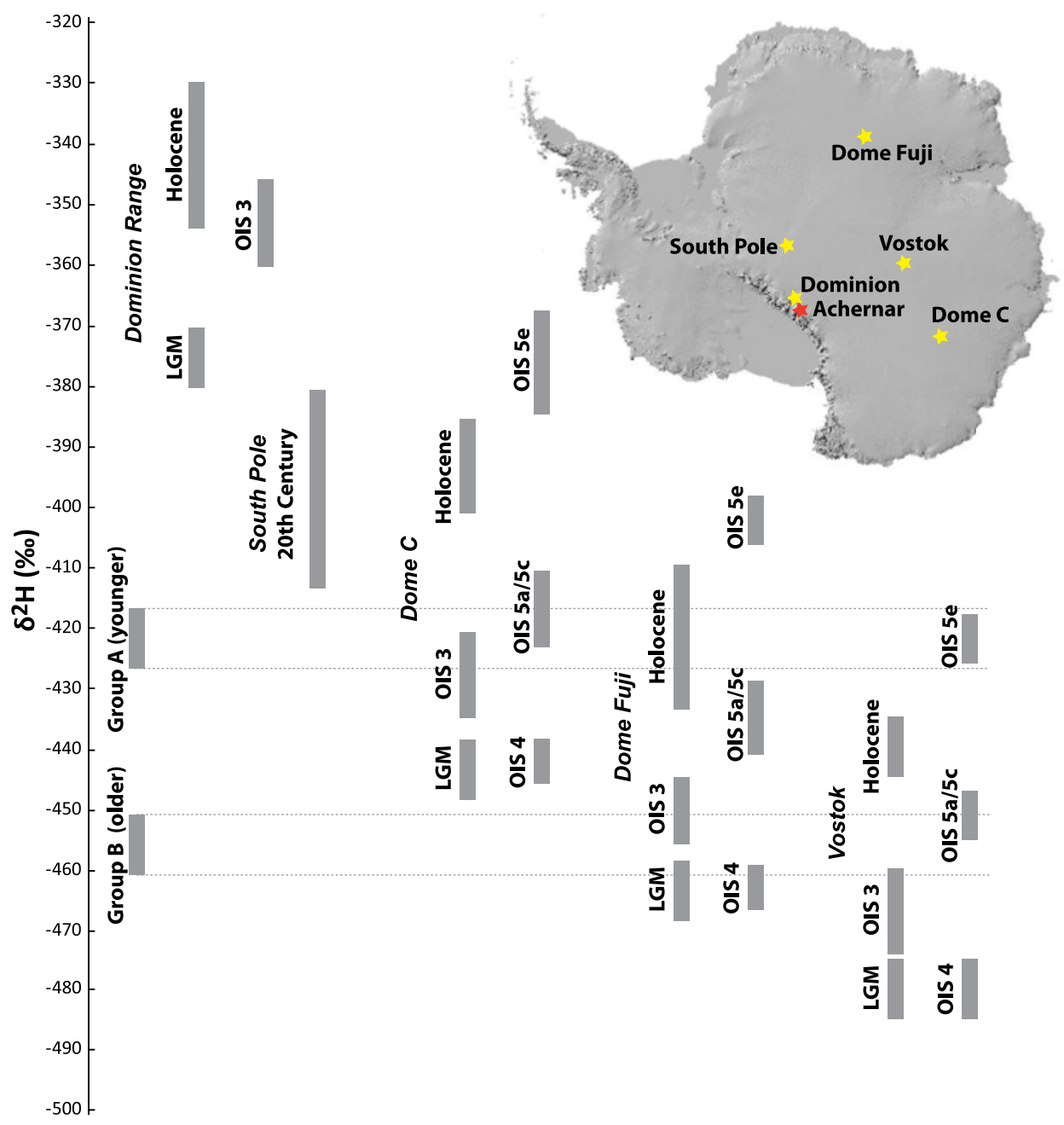

Fig. 6. For different glacial and interglacial periods from five Antarctic ice cores, we plot $\delta \mathrm{D}$. We compare these values with $\delta \mathrm{D}$ values from the intersections of the Std dev. from the trend through both isotope groups with the meteoric waterline (Fig. 4). The $\delta \mathrm{D}$ values for the Dominion Range core are inferred from the published $\delta^{18} \mathrm{O}$ values (Mayewski and others, 1990), by assuming a respective composition on the global meteoric waterline. All other $\delta \mathrm{D}$ values are from published literature. Note that the difference between group $\mathrm{A}$ and $\mathrm{B}$ is substantially larger than the difference between OIS 3 and the LGM or OIS 4.

2004), and OIS 5e values from Vostok (Petit and others, 1999). The enrichment trend for group $B$ intersects the meteoric waterline at $\sim \delta^{18} \mathrm{O}=-58.3 \%$, $\delta \mathrm{D}=-456 \%$, comparable with LGM values from Dome Fuji and OIS 5a/ 5c Pleistocene interstadials from Vostok (Fig. 6). The difference between the groups is $\sim 30 \%$ oD. At most Antarctic ice core sites on the polar plateau, the difference between the mid-Holocene and the LGM is $\sim 40 \%$ o $\delta$, whereas the most recent Pleistocene interstadial (OIS 3) is $\sim 20 \%$ o $\delta$ above the LGM. Approximately $30 \%$ o $\delta$ differences are found between OIS $5 \mathrm{a} / 5 \mathrm{c}$ and extreme stadials such as oxygen isotope stages 2,4 and 6 .

It is difficult to reconcile a Holocene ice age for group A with the $\sim 1000 \mathrm{~km}$ distance between Mount Achernar and regions with $>3500 \mathrm{~m}$ elevation on the polar plateau, where Holocene ice of group A's isotopic composition is found. Ice surface velocities are order of $10 \mathrm{~m} \mathrm{a}^{-1}$ or less for most of the distance (Rignot and others, 2011), an order of magnitude below the $\sim 100 \mathrm{~m} \mathrm{a}^{-1}$ transport speed needed to flux ice from the deep interior to Mount Achernar Moraine within Holocene time frames. We, therefore, consider it most likely that the groups A and B contrast Pleistocene interstadial and stadial periods. The clean ice and Law Glacier ice cores (group A) are from an interstadial period, whereas the moraine ice (group B) is from a stadial period. Because the rate of motion is higher, we suspect that Law Glacier ice is younger than the ice underlying the moraine. So, the stadial period probably pre-dates the interstadial period. Because the difference in isotopic enrichment between the groups is larger than the difference between marine isotope stages 3 and 4 in interior ice cores (Fig. 6), we infer that the ice from group A formed during OIS 5a at the earliest. This means that the ice in Law Glacier is $>80000$-years old and the ice underlying the moraine is probably older still. Near the edge of the moraine, the difference between stadial and interstadial ice is expressed on a short $(<10 \mathrm{~m})$ spatial scale, with clean ice adjacent to the moraine forming during an interstadial and sedimentbearing ice supplying the moraine forming during a stadial. Because sediment-bearing stadial ice is interleaved with clean interstadial ice, the ice was likely sheared or thrust over before emerging into the blue ice area.

The time period in which the ice formed can be contrasted with the time period at which the sediment emerged on Mount Achernar Moraine to assess ice transport times. Sections of the Mount Achernar Moraine contain sediment that emerged from the ice within the past 1-6 ka (Kaplan and others, 2017) and the oldest sediment from under 

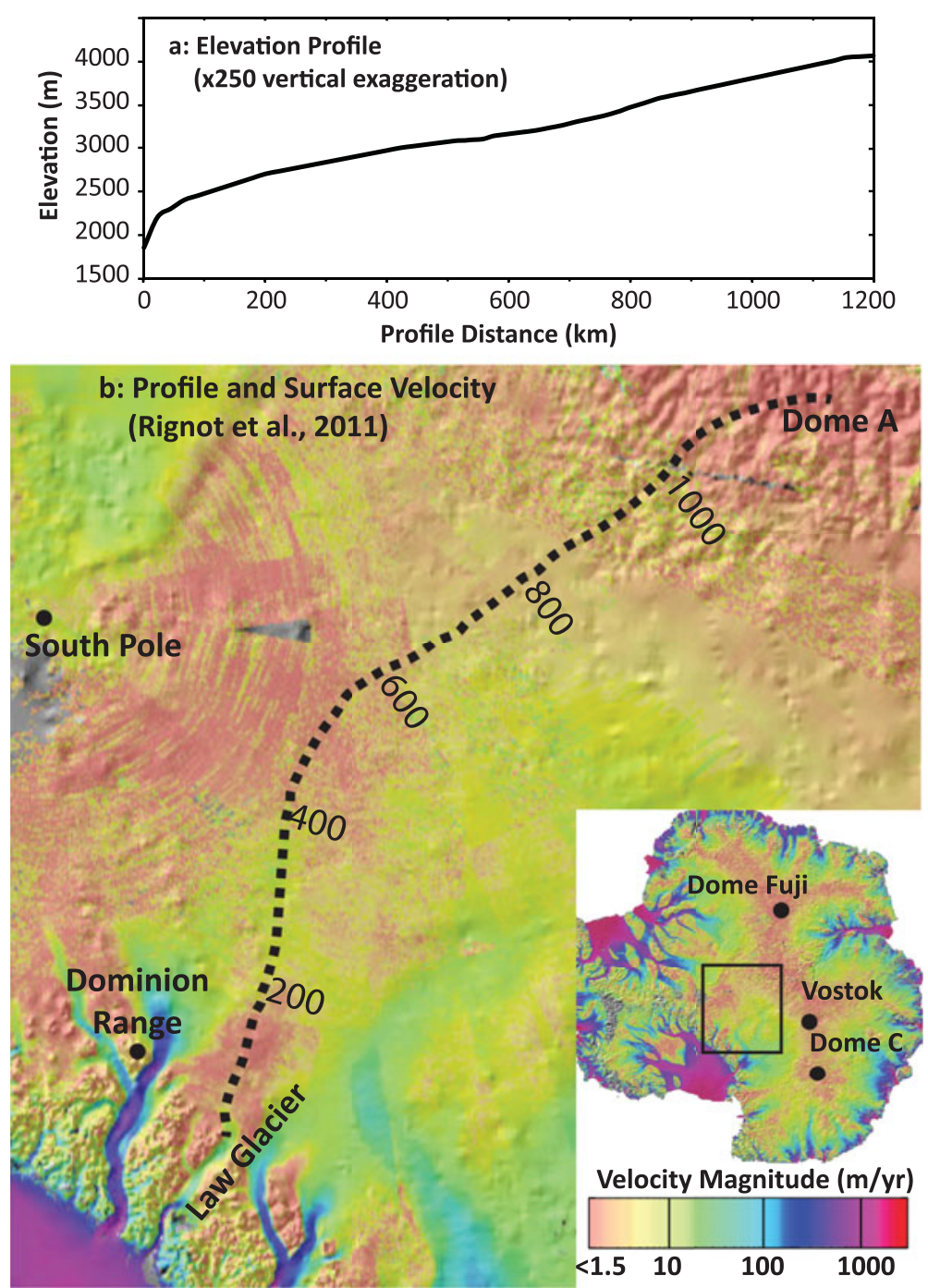

Fig. 7. Modeled flowline for ice supplied to Mount Achernar Moraine, based on MJ Hoffman's (personal communication) implementation of the Albany/FELIX model. The elevation profile for the flowline is shown in (a); modeled ice surface velocities from Rignot and others (2011) are shown in (b).

which ice samples were collected is LGM age ( 20-30 ka) (Fig. 2). Since the isotopes suggest that this ice formed during a Pleistocene stadial period on the high elevation interior of the polar plateau, ice transport times $>80000$ years are suggested. In its contemporary configuration, the fast-moving ice that feeds Law Glacier extends only 50 $\mathrm{km}$ inland onto the plateau from Mount Achernar (Rignot and others, 2011) (Fig. 7). Beyond is a region of very slowmoving ice $\left(<2 \mathrm{~m} \mathrm{a}^{-1}\right.$ surface velocity), extending for another $\sim 200 \mathrm{~km}$ along flowline direction toward the interior (Fig. 7). Another slow spot in the flowline occurs between 400 and $600 \mathrm{~km}$, corresponding to a relatively flat region in the vertical profile (Fig. 7). Basal ice velocities through the slow spots as modeled with the Albany/FELIX model (Tezuar and others, 2015) are $<1 \mathrm{~m} \mathrm{a}^{-1}$ (MJ Hoffman, personal communication). If the ice fluxing into Mount Achernar moraine was transported from the interior as basal ice, it possibly is multiple hundreds of thousands of years old.

We consider the slow spot between 400 and $600 \mathrm{~km}$ along the flowline (Fig. 7) to be the most plausible source of the ice sampled at Mount Achernar Moraine. The region is a few hundred meters higher in elevation than the South
Pole and based on altitude and continentality would likely have stable isotope values intermediate to those found at Dome C and those found at Dome Fuji (Fig. 6). Surface ice could plausibly transit the distance in 80-100 ka at the velocities modeled by Rignot and others (2011), making group A from OIS 5 and group B from OIS 6 at the earliest. However, alternative interpretations of the isotope and flowline data are also possible.

The distance and time needed to transport the ice from its formation location to Mount Achernar Moraine need not correspond to the residence time nor transport distance of the entrained sediment. Mount Achernar Moraine contains few exotic erratics, suggesting that most of the rock material in the moraine has a provenance similar to the local Beacon Formation bedrock (Bader and others, 2017). Furthermore, the regelation mechanism of sediment entrainment requires that the water pressure in the subglacial sediment drop below the ice overburden pressure (Philip, 1980). Lower subglacial water pressures are associated with faster ice velocities (Iken and Bindschadler, 1986; Stearns and others, 2008); whereas slower ice velocities and rising water pressures reverse the freezing front and melt glacial sediment from the basal ice layer. Because ice velocities increase 
$<50 \mathrm{~km}$ from the moraine and are very slow up flowline from there (Fig. 7), we consider the fast-flowing ice above the head of Law Glacier to be the most likely location of sediment entrainment. However, given the interior location of ice formation, we cannot definitively rule out the transport of some sediment from much deeper in the interior.

\section{CONCLUSIONS}

At Mount Achernar Moraine, in the Transantarctic Mountains, ice samples taken from beneath the sediment on the moraine have textures and stable isotope values consistent with sediment entrainment through open system regelation in basal ice that was at pressure melting point temperatures. On the surface of Law Glacier, where an emerging debris band is found outside of the moraine, there is less evidence of internal melting or regelation enrichment, leaving open the possibility that the sediment there was primarily or partially entrained through cold-based processes.

Once corrected by tracing the enrichment trend back to the meteoric waterline, the moraine ice has stable isotope values consistent with its formation during Pleistocene stadial phases in the interior of the polar plateau. This is true even in the portions of the moraine where sediment has only accumulated on the surface during the recent Holocene, which necessitates ice transport times $>80000$ years and possibly much longer. The emerging debris band on Law Glacier is formed from interstadial age ice, which also must be sourced from the interior of the polar plateau. We consider an OIS 5 age for the Law Glacier ice and at least an OIS 6 age for the basal ice feeding the moraine to be the most plausible explanation of the findings.

The Mount Achernar Moraine consists of ice from the polar plateau that entrained sediment under warm-based conditions, most likely by regelation. It contrasts with sediment bands in an adjacent portion of Law Glacier, which may not have entrained sediment through warm-based processes. These results confirm models that show warmbased ice near the Transantarctic Mountains (e.g. Pattyn, 2010) and suggest that blue ice moraines elsewhere on the continent may also be repositories of sediment and ice from the warm-based portions of the polar plateau. This suggests active erosion in the subglacial sediment source regions for these blue ice sites.

\section{ACKNOWLEDGEMENTS}

This work was supported by National Science Foundation Antarctic grants PLR-1443433 and PLR-1443213. The US Antarctic Program, Kenn Borek Air, Ltd., and field team members P. Braddock and K. Lindback are gratefully acknowledged for field and laboratory support. W. Propes performed the stable isotope analyses. K. Joy and C. Schrader collected and prepared the ANSMET ice water samples from 2012. Three thoughtful reviews and editorial handling by Michelle Koutnik and Hester Jiskoot improved the manuscript. This is LDEO contribution $\# 8190$.

\section{REFERENCES}

Alley RB and 5 others (1997) How glaciers entrain and transport basal sediment: physical constraints. Quat. Sci. Rev., 16, 10171038
Atkins CB, Barrett PJ and Hicock SR (2002) Cold glaciers erode and deposit: evidence from Allan Hills, Antarctica. Geology, 30(7), 659-662

Augustin L and 55 others (2004) Eight glacial cycles from an Antarctic ice core. Nature, 429(6992), 623-628

Bader NA, Licht KJ, Kaplan MR, Kassab C and Winckler G (2017) East Antarctic ice sheet stability recorded in a high-elevation ice-cored moraine. Quat. Sci. Rev., 159, 88-102

Bintanja R (1999) On the glaciological, meteorological, and climatological significance of Antarctic blue ice areas. Rev. Geophys., 37(3), 337-359

Chinn TJH (1991) Polar glacier margin and debris features. Mem. Soc. Geol. It., 46, 25-44

Christoffersen P, Tulaczyk S, Carsey FD and Behar AE (2006) A quantitative framework for interpretation of basal ice facies formed by ice accretion over subglacial sediment. J. Geophys. Res., 111, F01017

Cowan EA, Christoffersen P and Powell RD (2012) Sedimentological signature of a deformable bed preserved beneath an ice stream in a late Pleistocene glacial sequence, Ross Sea, Antarctica. J. Sediment. Res., 82, 270-282

Cuffey KM and 7 others (2000) Entrainment at cold glacier beds. Geology 28(4), 351-354

Dansgaard W (1964) Stable isotopes in precipitation. Tellus, 16(4), 436-468

Dash JG, Rempel AW and Wettlaufer JS (2006) The physics of premelted ice and its geophysical consequences. Rev. Mod. Phys., 78, 695-741

Fitzsimons S and 5 others (2008) Mechanisms of basal ice formation in polar glaciers: an evaluation of the apron entrainment model. J. Geophys. Res., 113, F02010

Fogwill CJ, Hein AS, Bentley MJ and Sugden DE (2012) Do blue-ice moraines in the Heritage Range show the West Antarctic ice sheet survived the last interglacial? Palaeogeogr. Palaeoclimatol. Palaeoecol., 335-336, 61-70

Fretwell P and 9 others (2013) Bedmap2: improved ice bed, surface and thickness datasets for Antarctica. Cryosphere, 7(1), 375393

Geldern R and Barth JA (2012) Optimization of instrument setup and post-run corrections for oxygen and hydrogen stable isotope measurements of water by isotope ratio infrared spectroscopy (IRIS). Limnol Oceanogr Methods, 10(12), 1024-1036

Glasser NF and Hambrey MJ (2002) $\delta D-\delta^{18} \mathrm{O}$ relationships on a polythermal valley glacier: Midtre Lovénbreen, Svalbard. J. Glaciol., 21 (1), 123-131

Gordon JE, Darling WG, Whalley WB and Gellatly AF (1988) $\delta \mathrm{D}-\delta$ $18 \mathrm{O}$ relationships and the thermal history of basal ice near the margins of two glaciers in Lyngen, North Norway. J. Glaciol., 34(118), 265-268

Gow AJ (1971) Relaxation of ice in deep drill cores from Antarctica. J. Geophys. Res., 76(11), 2534-2541

Hallet B, Hunter L and Bogen J (1996) Rates of erosion and sediment evacuation by glaciers: a review of field data and their implications. Glob. Planet. Change, 12, 213-235

Hubbard B and Sharp M (1993) Weertman regelation, multiple refreezing events and the isotopic evolution of the basal ice layer. J. Glaciol., 39(132), 275-291

Hubbard B and Sharp M (1995) Basal ice facies and their formation in the Western Alps. Arct. Alp. Res., 27(4), 301-310

Iverson NR and Souchez R (1996) Isotopic signature of debris-rich ice formed by regelation into a subglacial sediment bed. Geophys. Res. Lett., 23, 1151-1154

lizuka Y, Stake H, Shiraiwa T and Naruse R (2001) Formation processes of basal ice at Hamma Glacier, Soya Coast, East Antarctica, inferred by detailed co-isotopic analyses. J. Glaciol., 47(157), 223-231

Iken A and Bindschadler RA (1986) Combined measurements of subglacial water pressure and surface velocity of Findelengletscher, Switzerland: conclusions about drainage system and sliding mechanism. J. Glaciol., 32(110), 101-119 
Johnsen SF and 14 others (1997) The $\delta^{18} \mathrm{O}$ record along the Greenland Ice Core Project deep ice core and the problem of Eemian climatic instability. J. Geophys. Res., 102, 26397-26410

Johnsen SJ and 8 others (2001) Oxygen isotope and paleotemperature records from six Greenland ice-core stations: Camp Century, Dye-3, GRIP, GISP2, Renland, and NorthGRIP. J. Quat. Sci., 16(4), 299-307

Jouzel J and Souchez RA (1982) Melting-refreezing at the glacier sole and the isotopic composition of the ice. J. Glaciol., 28(98), 35-42

Jouzel J, Merlivat L, Petit JR and Lorius C (1983) Climatic information over the last century deduced from a detailed isotopic record in the South Pole snow. J. Geophys. Res., 88(C4), 2693-2703

Jouzel J and 11 others (1995) The two-step shape and timing of the last deglaciation in Antarctica. Clim. Dyn., 11, 151-161

Kaplan MR and 9 others (2017) Mid-late Pleistocene stability of the central East Antarctic Ice Sheet at the head of Law Glacier. Geology 11, 963-966

Kassab C and 5 others (2016) The development of blue ice moraines from englacial debris bands as detected by GPR, Mt Achernar, central Transantarctic Mountains, Antarctica. American Geophysical Union, Abstracts with Programs

Knight PG (1989) Stacking of basal debris layers without bulk freezing-on: isotopic evidence from West Greenland. J. Glaciol., 45 (129), 214-216

Knight PG (1994) Two-facies interpretation of the basal layer of the Greenland ice sheet contributes to a unified model of basal ice formation. Geology, 22, 971-974

Knight PG (1997) The basal ice layer of glaciers and ice sheets. Quat. Sci. Rev., 16, 975-993

Knight PG, Sugden DE and Minty CD (1994) Ice flow around large obstacles as indicated by basal ice exposed at the margin of the Greenland ice sheet. J. Glaciol., 40(135), 359-367

Lawson DE and 5 others (1998) Glaciohydraulic supercooling: a freeze-on mechanism to create stratified, debris-rich basal ice. J. Glaciol., 44, 547-562

Lehmann M and Siegenthaler U (1991) Equilibrium oxygen- and hydrogen-isotope fractionation between ice and water. J. Glaciol., 37, 23-26

Licht KJ and Hemming SR (2017) Analysis of Antarctic glaciogenic sediment provenance through geochemical and petrologic applications. Quat. Sci. Rev., 164, 1-24

Licht K and Palmer E (2013) Erosion and transport by Byrd Glacier, Antarctica during the last glacial maximum. Quat. Sci. Rev., 62, 32-48

Lipenkov VY (2000) Air bubbles and air-hydrate crystals in the Vostok ice core. In Hondoh T, ed. Physics of ice core records. Hokkaido University Press, Sapporo, Japan, 327-358

Masson V and 13 others (2000) Holocene climate variability in Antarctica based on 11 ice-core isotopic records. Quatern. Res., 54, 348-358

Mayewski PA and 9 others (1990) The dominion range ice core, Queen Maud Mountains, Antarctica-General site and core characteristics with implications. J. Glaciol., 36(122), 11-16

Moser H and Stichler W (1980) Environmental isotopes in ice and snow. In Fritz P and Fontes JC, eds. Handbook of Environmental Isotope Geochemistry, vol. 1, Elsevier, Amsterdam, 141-178

Nakaya $U$ (1956) Properties of single crystals of ice revealed by internal melting. In Engineers, U.A.C.o., ed., 80. Snow Ice and Permafrost Research Establishment Research Paper 13. Snow, Ice and Permafrost Research Establishment, Corps of Engineers, U.S. Army

Palmer EF, Licht KJ, Swope RJ and Hemming SR (2012) Nunatak moraines as a repository of what lies beneath the East Antarctic ice sheet. In Rasbury ET, Hemming SR and Riggs NR, eds. Mineralogical and geochemical approaches to provenance: geological society of America special paper, vol. 487, Geological Society of America, 97-104

Pattyn F (2010) Antarctic subglacial conditions inferred from a hybrid ice sheet/ice stream model. Earth Planet. Sci. Lett., 295, 451-461

Petit JR and 18 others (1999) Climate and atmospheric history of the past 420,000 years from the Vostok ice core, Antarctica. Nature, 399(6735), 429-436

Philip RJ (1980) Thermal fields during regelation. Cold. Reg. Sci. Technol., 3, 193-203

Rignot E, Mouginot J and Scheuchl B (2011) Ice flow of the Antarctic ice sheet. Science, 333, 1427-1430

Scarrow JW, Balks MR and Almond PC (2014) Three soil chronosequences in recessional glacial deposits near the polar plateau, in the Central Transantarctic Mountains, Antarctica. Antarct. Sci. 26(5), 573-583

Sokratov SA and Golubev VN (2009) Snow isotopic content change by sublimation. J. Glaciol., 55(193), 823-828

Souchez RA and de Groote JM (1985) $\delta \mathrm{D}-\delta^{18} \mathrm{O}$ relationships in ice formed by subglacial freezing: paleoclimatic implications. J. Glaciol., 31(109), 229-232

Souchez R and Jouzel J (1984) On the isotopic composition in $\delta \mathrm{D}$ and $\delta^{18} \mathrm{O}$ of water and ice during freezing. J. Glaciol., 30, 369372

Souchez R and 5 others (1990) Influence of hydroxyl-bearing minerals on the isotopic composition of ice from the basal zone of an ice sheet. Nature, 345, 244-246

Souchez R and 7 others (1994) Stable isotopes in the basal silty ice preserved in the Greenland Ice Sheet at Summit; environmental implications. Geophys. Res. Lett., 21, 693-693

Stearns LA, Smith BE and Hamilton GS (2008) Increased flow speed on a large East Antarctic outlet glacier caused by subglacial floods. Nat. Geosci., 1(12), 827

Stichler W and 6 others (2001) Influence of sublimation on stable isotope records recovered from high-altitude glaciers in the tropical Andes. J. Geophys. Res., 106(D19), 22613-22620

Sugden DE and 6 others (1987) Evidence for two zones of debris entrainment beneath the Greenland ice sheet. Nature, 328(16), 238-241

Sugden DE and 5 others (2014) Emergence of the Shackleton range from beneath the Antarctic ice sheet due to glacial erosion. Geomorphology, 208, 190-199

Tezuar IK, Perago M, Salinger AG, Tuminaro RS and Price SF (2015) Albany/FELIX: a parallel, scalable and robust, finite element, firstorder stokes approximation ice sheet solver built for advanced analysis. Geosci. Model Dev., 8, 1-24

Tison JL, Petit JR, Barnola JM and Maheney WC (1993) Debris entrainment at the ice-bedrock interface in sub-freezing temperature conditions (Terre Adelie, Antarctica). J. Glaciol., 39(132), 303-315

Turney C and 7 others (2013) Late Pleistocene and early Holocene change in the Weddell Sea: a new climate record from the Patriot Hills, Ellsworth Mountains, West Antarctica. J. Quat Sci., 28(7), 697-704

Uemura R and 5 others (2012) Ranges of moisture-source temperature estimated from Antarctic ice cores stable isotope records over glacial-interglacial cycles. Clim. Past, 8(3), 1109-1125

Van Liefferinge B and Pattyn F (2013) Using ice-flow models to evaluate potential sites of million year-old ice in Antarctica. Clim. Past, 9, 2335-2345

Weertman J (1961) Mechanism for the formation of inner moraines found near the edge of cold ice caps and ice sheets. J. Glaciol., 3(30), 965-978

Whillans IM and Cassidy WA (1983) Catch a falling star: meteorites and old ice. Science, 222, 55-57 